\title{
CLADOSPORIUM SPORES IN THE AIR OF SZCZECIN
}

\author{
Agnieszka Grinn-Gofroń \\ Department of Plant Taxonomy and Phytogeography, University of Szczecin, Wąska 13, 71-415 Szczecin, Poland \\ e-mail: agofr@univ.szczecin.pl
}

Received: 20.10 .2007

\begin{abstract}
A b s tract
Moulds are common aeroallergens and Cladosporium is considered to be the most prevalent of them. The objective of the studies was to determine the seasonal variation in concentrations of Cladosporium spores due to meteorological parameters. The meteorological parameters analysed were maximum air temperature, relative humidity, amount of precipitation and wind speed.

The greatest threat from Cladosporium allergens was posed from the middle of May $(2004,2006)$ and June (2005) till the middle of October (2005) and in the end of October (2004) till the middle of November (2006).

Statistically significant correlations were found among the Cladosporium spore count in the air and maximum air temperature in all the analysed seasons, and amount of precipitation only in one season. The spore count of Cladosporium was determined by weather conditions, especially by air temperature.
\end{abstract}

Key words: Cladosporium, airborne spores, meteorological factors, Western Pomerania, Poland

\section{INTRODUCTION}

Cladosporium spores are reported to form a majority of airborne spores in the temperate zones (D a v i e s 1969, S o l o m o n 1978). Cladosporium species live as saprophytes or as parasites on many kinds of plants. Dry spores produced in excessive quantities can be transported over wide areas, even oceans. Recordings from all parts of the world show that with a few exceptions Cladosporium is the most frequently encountered mould in the air. Its temperature optimum ranges $18-28^{\circ} \mathrm{C}$, but growth down to $-6^{\circ}$ is also possible ( $\mathrm{Gr}$ a v e s e $n$, 1979).

There is a great seasonal variation in the concentration of Cladosporium conidia in the air; the highest concentrations occur during the summer from June to September (A insw orth, 1952; Hyde and Wi liams 1953; Ballero et al. 1984, Ebner et al. 1989; H a lw a g y, 1989).
Generally, conidial production and dispersal in Cladosporium depend on precipitation, temperature, and the amount of available growth medium. High atmospheric spore concentrations can develop only when dead plant material, e.g decidous trees, freshly cut branches or twigs, are present as a medium ( $\mathrm{K} \mathrm{u} \mathrm{rk} \mathrm{e} \mathrm{-}$ la, 1974) or dense vegetation continuously provides suitable media for conidial production $(\mathrm{H}$ a $\mathrm{l}$ a w a g y, 1989).

Even though mould spores are present in the air in concentrations considerably greater than those of pollen grains, the frequency of allergic respiratory diseases due to moulds is usually much lower than due to pollen grains of vascular plants (D' A mato and Spieks m a, 1995).

The aim of the study was to analyse the Cladosporium season in Szczecin (western Poland) in 2004-2006 and to establish a relationship between meteorological conditions and the Cladosporium spore amounts.

\section{MATERIALS AND METHODS}

The results of investigation are based on aerobiological monitoring performed in Szczecin in 2004-2006. The Lanzoni 7 Day Recording Trap was installed on the roof top in Szczecin city district Sródmieście, at the height of $21 \mathrm{~m}$ above ground level (52 $\mathrm{m}$ above sea level).

Meteorological data covering three years of study were provided by the Automatic Weather Station (Vaisala, Finland). The meteorological parameters taken into regard in the assessment of the effect of meteorological conditions on airborne fungal spores were as follows: daily level of precipitation, wind speed, relative humidity and air temperature.

The degree of correlation between particular meteorological parameters and the concentration of Cladosporium spores was described by the Pearson's correlation coefficient $r$ (statistical error risk was estimated 
at the significance level of $95 \%, \alpha=0.05)(\mathrm{Ok} \mathrm{ta} \mathrm{b} \mathrm{a}$, 1980).

The spore data were analysed to determine the start, end and duration of the season using the $90 \%$ method.

\section{RESULTS}

Spores of Cladosporium were found in the air in Szczecin practically throughout the whole year, with the exception of periods when temperature drops below $0^{\circ} \mathrm{C}$ (usually January-February and sometimes December).

Spores of Cladosporium were recorded every day during the years 2004, 2005 and 2006. The concentration during the spore season ranged from 177 spores $\times \mathrm{m}^{-3}$ on 23 May to the annual peak of 31098 spores $\times \mathrm{m}^{-3}$ on 8 July in 2004 , from 24 spores $\times \mathrm{m}^{-3}$ on 6 July to the annual peak of 22737 spores $\times \mathrm{m}^{-3}$ on 28 July in 2005, and from 63 spores $\times \mathrm{m}^{-3}$ on 17 June to the annual peak of 19560 spores $\times \mathrm{m}^{-3}$ on 6 August in 2006 (Fig. 1).

The lowest total number of sporomorphs (39 6063) was noted in 2006, while in the other seasons its values were markedly higher (Tab. 1). The highest maximum spore count was noted in 2005 and it was equal to 675286 spores $\times \mathrm{m}^{-3}$ per $24 \mathrm{~h}$ (Tab. 1, Figs 1,2 ).

During the three years analysed, the maximum Cladosporium spore count was noted more or less in the middle of the spore season. The differences (a few days in every year) were caused by weather conditions. The vegetation season in 2004 and 2006, in comparison with 2005 , started later because of frosty winter and cold spring. In 2005 the spring was dry and warm, and the spore season was the shortest and most intensive.

Based on the results of analysis of spore season duration, a conclusion may be drawn that shorter spore seasons are characterised by higher annual sums of sporomorphs.

Starting from the third decade of May and the second decade of June in 2006 to the first decade of October, the spore count was high in the air over Szczecin. In 2004 and 2005 the period in which the Cladosporium spore count exceeded the threshold value of 2800 spores $\times \mathrm{m}^{-3}$ per $24 \mathrm{~h}$ in Szczecin lasted 78-79 days. In 2006 it was shorter and lasted only 43 days (Tab. 1).

In 2004 and 2005 climatic conditions were favourable for Cladosporium growth and dispersal. The annual total count for both years was over 620000 spores $\cdot \mathrm{m}^{-3}$ which is ca. $40 \%$ higher than in 2006.

The growth, sporulation and dispersal of Cladosporium seem to be sensitive to changes in the climatic situation. In some of the seasons studied, the Cladosporium spore count was statistically significantly correlated with the weather factors analysed (Tab. 2).

In all the seasons, the Cladosporium spore count was positive and statistically significantly correlated with maximum air temperature. Only in one out of the three seasons studied, a positive and statistically significant correlation was noted between the Cladosporium spore count and rainfall (Tab. 2).

Cladosporium as dry airspora is favoured by high temperature. If the temperature rises above $18^{\circ} \mathrm{C}$, the Cladosporium concentration increases.

Table 1

Results of aerobiological study of Cladosporium spores counts.

\begin{tabular}{rcccc}
\hline Taxon & & 2004 & 2005 & 2006 \\
\hline \multirow{2}{*}{ Cladosporium } & ss & $19 \mathrm{~V}-28 \mathrm{X}$ & $14 \mathrm{VI}-11 \mathrm{X}$ & $23 \mathrm{~V}-16 \mathrm{XI}$ \\
& & $(163)$ & $(120)$ & $(178)$ \\
& tn & 628095 & 675286 & 396063 \\
& $\max$ & 31098 & 22737 & 19560 \\
& tsc & 79 & 78 & 43 \\
\hline
\end{tabular}

ss - spore season established by the $90 \%$ method (with number of days),

tn - total number of Cladosporium spores collected in the spore season established by the $90 \%$ method, $\max$ - maximum number of spores per $24 \mathrm{~h}$, tsc - the number of days with spores count above 2800 spores in $1 \mathrm{~m}^{3}$ threshold of spores count at which allergy symptoms develop (Rapiejko et al. 2004). 
Table 2

Correlation coefficients between Cladosporium spores counts and meteorological factors.

\begin{tabular}{|c|c|c|c|c|c|}
\hline \multirow[b]{2}{*}{ Taxon } & \multirow[b]{2}{*}{ Years } & \multicolumn{4}{|c|}{ Meteorological factors } \\
\hline & & Temperature $\max .\left({ }^{\circ} \mathrm{C}\right)$ & Rainfall (mm) & $\begin{array}{l}\text { Wind speed max. } \\
\qquad(\mathrm{m} / \mathrm{s})\end{array}$ & $\begin{array}{l}\text { Relative humidity } \\
(\%)\end{array}$ \\
\hline \multirow[t]{3}{*}{ Cladosporium } & 2004 & $0.2915^{*}$ & 0.1399 & -0.0918 & -0.0419 \\
\hline & 2005 & $0.3711^{*}$ & -0.0392 & 0.0653 & -0.0586 \\
\hline & 2006 & $0.3044^{*}$ & $0.1658^{*}$ & 0.0006 & -0.0720 \\
\hline
\end{tabular}

* Correlation statistically significant $(\mathrm{p}<0.05)$.
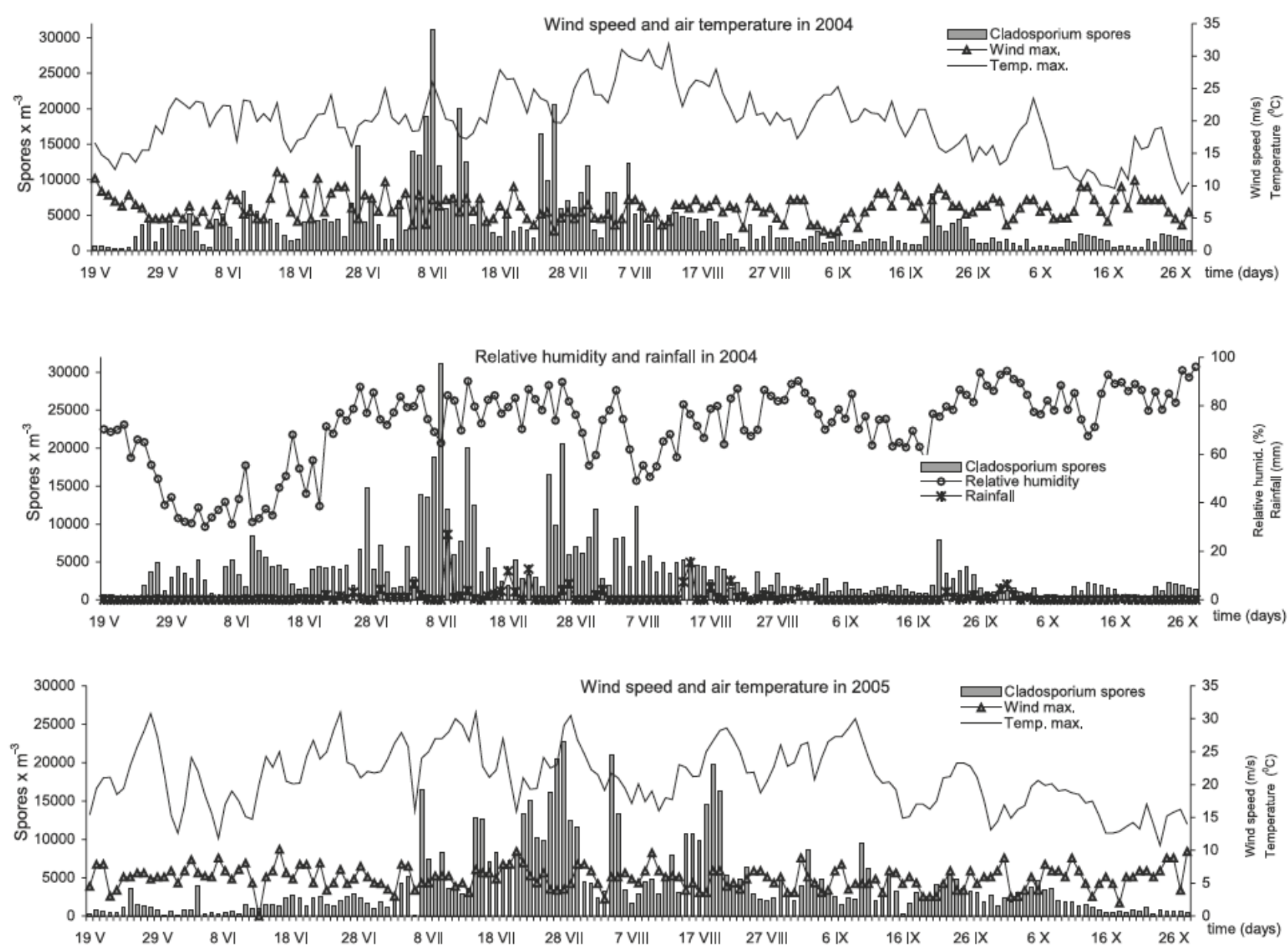

Fig. 1. Correlation among number of Cladosporium spores and relative humidity, rainfall, wind speed and air temperature in 2004, 2005 and 2006. 

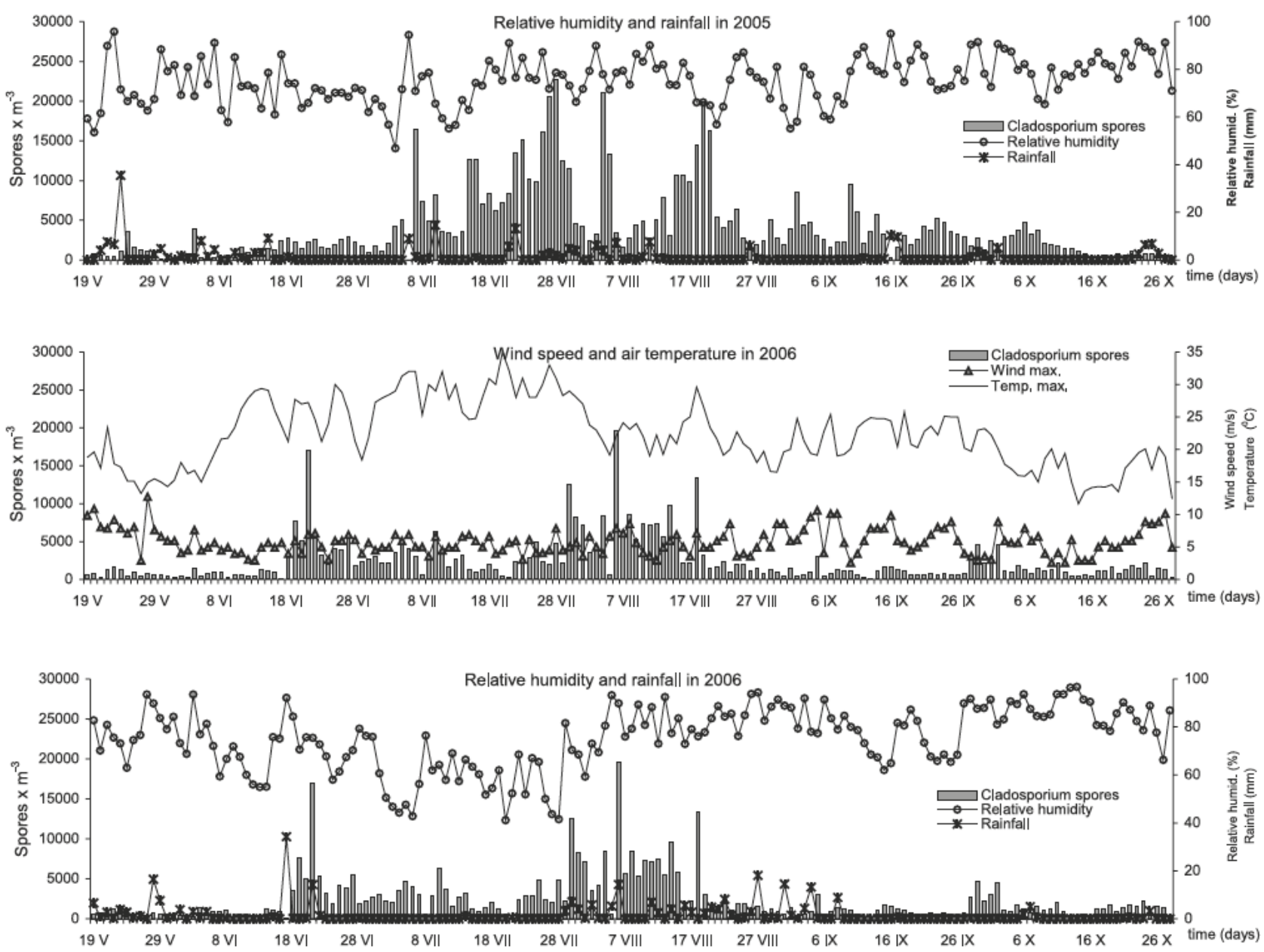

cd. Fig. 1.

\section{DISCUSSION}

In Szczecin the highest number of Cladosporium spores was usually encountered during summer (July and August). Before and after that period (May and September), the spore concentration level was also high, but clearly lower than in summer.

The highest concentration of Cladosporium during summer was observed by $\mathrm{H} \mathrm{j} \mathrm{e} \mathrm{m} \mathrm{roos}$ (1993) in Sweden and by S tę pa ls k a et al. (1999) in Poland.

The contrary occurrence was noted in Spain ( $\mathrm{In}$ fante and Dominquez, 1988) and on Sardinia (C o s e ntin o et al. 1990), where a decrease in spore concentration was observed during summer. This situation was associated with the lack of rain and very high air temperature (C o s e n t in o et al.1990). In Jordan spores of Cladosporium are the most common in the air due to the wet and warm season and maximum spore counts is noted in October ( $\mathrm{S} \mathrm{h}$ a n e e $\mathrm{n}, 1992)$.
In Szczecin the daily Cladosporium spore concentration has a positive, significant correlation with maximum temperature. The same correlation was noted in southern Poland (S t ę p a l sk a and Wo łek, 2005), Finland (Kurkela, 1997), Sweden ( $\mathrm{Hj}$ e l mroos, 1993), Spain (Fernandez et al. 1998) and New Zealand (H a s nain, 1993). Has nain (1993) also reported the strongest correlation between the Cladosporium spore count and maximum day temperature in comparison with concentrations of other airborne fungal spores. Green burg et al. (1964, 1966) considered that in some cases a mere change in ambient air temperature can provoke asthma symptoms in some patients.

The Cladosporium spore count was positive and statistically significantly correlated with rainfall only in one analysed season (2006).

A slight correlation between precipitation and the number of Cladosporium spores was observed in Finland by K u r k e l a (1997). Only in one season, rain 
had a significant correlation with the number of spores counted 14 hours later.

$\mathrm{H} \mathrm{jel} \mathrm{m} \mathrm{roos} \mathrm{(1993)} \mathrm{noted} \mathrm{that} \mathrm{the} \mathrm{increase} \mathrm{of}$ atmospheric concentrations after the rainfall is generally long lasting, with the peak observed some hours after the rain. $\mathrm{M}$ it a k a k is et al. (1997) reported a negative correlation with rain for Cladosporium.

During the analysed seasons, the correlation between the Cladosporium spore concentration and wind speed did not show a statistically significant correlation. The same results were noted by L e v e t in and D or sey (2006), Hasnain (1993), Lopez and Salv a g gi o (1983).

The wind speed was clearly associated with spore dispersal in Finland (Kurke la, 1997). The long distance dispersal of spores depends on wind conditions, but the detachment of spores dispersed in dry conditions is also strongly influenced by wind ( $\mathrm{Malla} \mathrm{iah}$ and $\mathrm{R}$ a o, 1982).

Similar results occurred regarding relative humidity in Szczecin, 2004-2006. K u r k e la (1997), S t ę $\mathrm{pals} \mathrm{ka}$ and Wołek (2005) found a negative correlation between Cladosporium spore and relative humidity. During a rainy period, the level of spore concentration was low. Fernandez et al. (1998) reported that relative humidity, coupled with minimum temperature, was a factor affecting spore release. H a s n a i n (1993) did not observe any influence of relative humidity on Cladosporium spore concentration, contrary to other ascospores.

The high concentration and long lasting presence of Cladosporium in the air may cause and intensify clinical symptoms in people suffering from sensitivity and extend the period of presence of allergens in the atmosphere after the flowering season of vascular plants.

The presented results reflect the necessity of widening the spectrum of factors, e.g. weather variables, which may determine the level of spore concentrations.

\section{CONCLUSIONS}

- The higher Cladosporium spore concentration in Szczecin occurred in summer with peak periods in July (2004, 2005) and August (2006), and from June to October its concentration exceeded threshold values provoking allergy symptoms.

- The analysis of duration and dynamics of the Cladosporium spore seasons revealed that in the shorter spore seasons the annual sums of sporomorphs were high, while in the longer spore seasons these sums were lower.

- During all the seasons studied, the spore count of Cladosporium was positively statistically significantly correlated with maximum air temperature. A positive statistically significant correlation was also observed regarding rainfall during one spore season studied.
- The Cladosporium spores count in the air of Szczecin did not show a tendency to increase or decrease; however, this observation needs to be confirmed by long-term studies.

\section{Acknowledgements}

In 2005-2007 these researches were financed by KBN Grant No. 2, P04G 09929.

\section{REFERENCES}

A insworth G. C., 1952. The incidence of air-borne Cladosporium spores in the London region. J. Gen. Microbiol. 7: $358-361$.

Ballero M., Gioannis N. de Goretti G., Lombardibi S. and Frenquwlli G., 1984. Comparative study about airborne spores in Cagliari and Perugia. Aerobiologia, 8: 141-147.

Cosentino S., Pisano P. L., Fadda M. E. and Palmas F., 1990. Pollen and mould allergy: aerobiological survey in the atmosphere of Caligari, Italy (1986-1988). Ann. Allergy, 65: 393-399.

D'A mato G. and Spieksma F. Th. M., 1995. Aerobiologic and clinical aspects of mould allergy in Europe. Allergy, 50: 870-877.

Davies R. R., 1969. Spore concentrations in the atmosphere at Ahmadi, a new town in Kuwait. J. Gen. Microbiol. 55: 425-432

Ebner M. R., Haselwandter K. and Frank A., 1989. Seasonal fluctuations of airborne fungal allergens. Mycol. Res. 92: 170-176.

Fernandez D., Valencia R. M., Molner T., Vega A. and Sagŭes E., 1998. Daily and seasonal veriations of Alternaria and Cladosporium airborne spores in Leŏn (North-West, Spain). Aerobiologia, 14: 215-220.

Gravesen S., 1979. Fungi as a cause of allergic disease. Allergy, 34: 135-154.

Greenburg L., Field F., Reed J. and Erhard C. L., 1964. Asthma and Temperature change. An epidemiological study of emergency clinic visits for asthma in three large New York Hospitals. Arch. of Environ. Health. 8: 642-647.

Greenburg L., Field F., Reed J. and Erhard C. L., 1966. Asthma and Temperature change II. 1964 and 1965 epidemiological studies of emergency clinic visits for asthma in three large New York Hospitals. Arch. Environ. Health. 12: 561-563.

Halwagy M. H., 1989. Seasonal airspora at the three sites in Kuwait 1977-1982. Mycol. Res. 93: 208-213.

Hasnain S. M., 1993. Influence of meteorological factors on the air spora. Grana, 32: 184-188.

Hjelmroos M., 1993. Relationship between airborne fungal spore presence and weather variables. Grana, 32: 40-47.

Hyde H. A., and Wiliams D. A., 1953. The incidence of Cladosporium herbarium in the outdoor air at Cardiff, 1949-50. Trans. Br. Mycol. Soc. 36: 260-266. 
Infante F. and Dominquez E., 1988. Annual variation of Cladosporium spores in home habitats in Cordoba, Spain. Ann. Allergy, 60: 256-261.

Kurkela T., 1974. Colonization of Melampsora uredia on aspen leaves by Cladosporium sp. Commun. Inst. For. Fenniae, 80 (3).

Kurkela T., 1997. The number of Cladosporium conidia in the air in different weather conditions. Grana, 36: 54-61.

Levetin E. and Dorsey K., 2006. Contribution of leaf surface fungi to the air spora. Aerobiologia, 22: 3-12.

Lopez M. and Salvaggio E. J., 1983. Climate-WeatherAir pollution. [In:] Allergy: Principles and practice. 2 nd. E. Middleton, C. E. Reed \& E. F. Ellis (eds), Mosby, St. Louis, pp. 1203-1214.

Mallaiah K. V. and Rao A. S., 1982. Aerial dissemination of uredinospores of roundnut rust. Trans. Br. Mycol. Soc. 78: $21-28$.

Mitakakis T., Ong E. K., Stevens A., Guest D., Knox R. B., 1997. Incidence of Cladosporium, Alternaria and total fungal spores in the atmosphere of Melbourne (Australia) over 3 years. Aerobiologia, 13: 83-90.

Oktaba W., 1980. Elementy Statystyki Matematycznej i Metodyka Doświadczalnictwa. / Elements of Mathematical Statistics and Methodology of Experimental Science. PWN, Warszawa.

Rapiejko P, Lipiec A, Wojdas A, Jurkiewicz D., 2004. Threshold pollen concentration necessary to evoke allergic symptoms. Int. Rev. Allergol. Clin. Immunol. 10, 3: 91-94.

Shaneen I., 1992. Aeromycology of Amman area, Jordan. Grana, 31; 223-228.

Solomon W. R., 1978. Aerobiology and inhalent allergens. 1. Pollen and fungi. [In:] Allergy: Principles and practice. E. Middleton, C. E. Reed \& E. F. Ellis (eds), Mosby, St. Louis, pp. 312-372.

Stępalska D., Harmata K., Kasprzyk I., Myszkowska D., and Stach A. 1999. Occurence of airborne Cladosporium and Alternaria spores in Southern and Central Poland in 1995-1996. Aerobiologia, 15: 39-47.

Stępalska D. and Wołek J., 2005. Variation in fungal spore concentrations of selected taxa associated to weather conditions in Cracow, Poland, in 1997. Aerobiologia, 21: 43-52.

\section{Zarodniki rodzaju Cladosporium w powietrzu Szczecina}

\section{Streszczenie}

Celem pracy jest analiza sezonu rodzaju Cladosporium w Szczecinie w latach 2004-2006 i ustalenie powiązania pomiędzy czynnikami meteorologicznymi a koncentracją zarodników. Podczas trzech sezonów przeanalizowano korelację pomiędzy stężeniem zarodników Cladosporium a maksymalną temperaturą powietrza, wilgotnością względną, opadem i prędkością wiatru za pomoca metody wolumetrycznej. Czas trwania sezonu wyznaczono metodą $90 \%$. W ciągu trzech lat obserwacji najniższą dobową koncentrację zarodników Cladosporium zanotowano w 2006 roku z maksymalnym stężeniem wynoszącym 19560 zarodników na metr sześcienny. Najwyższa koncentracja wystąiła w 2004 a stężenie dobowe wyniosło wtedy 31098 zarodników na metr sześcienny.

Objawy uczulenia alergenami Cladosporium u osób wrażliwych występują przy stężeniu 2800 zarodników na metr sześcienny. Stężenia przekraczające wartości progowe notowane były $\mathrm{w}$ trzecim tygodniu maja (dla lat 2004 i 2005) i w czerwcu (2006) do połowy października (dla roku 2005), końca października (2004) i do połowy listopada (2006).

Statystycznie istotna korelacja wystapiła pomiędzy stężeniem zarodników Cladosporium a temperatura maksymalną i w roku 2006 z opadami. 